disease'. Another example on display is the replacement of the more expensive tortoise shell hair combs with celluloid hair combs. The new celluloid compounds were cheaper, but they were unstable and easily combustible: any heat source was enough to cause the comb to explode, whether in the factory or on a woman's vanity table. Economics also transcended class. The gentleman's stiff demands on polished boots paralleled the poor conditions of penniless and homeless shoeshine boys, who were found all over urban streets. The polishes they used for shining shoes frequently put their health at risk. A shoeshine boy's kit consisted of brushes, rags, polish and a box that also functioned as a stand for customers. Polish contained nitrobenzene; despite smelling quite pleasant, it oxidised iron in blood on contacted with the skin, causing dizziness, nausea, cyanosis and even death. Moreover, these boys were vulnerable to abuse from people taking advantage of their impoverished situation.

By approaching fashion history through material history, Fashion Victims connects the fashions of the aristocracy with the risks to poor factory workers to present a unique way of viewing our medical past. The exhibit's focus on parallel histories - the pleasures and perils - is even obvious in the space. As soon as you walk through the doors, a black and white floor and arched window displays welcome you. After walking through colourful and softly lighted displays, I turned a corner and found myself in a concrete area void of colour. Most of the displays on manufacturing and perils of factory workers are contained here, which supposedly is used to represent the bleakness of urban life. But honestly, I thought the exhibit was still under construction.

Fashion Victims: The Pleasures and Perils of Dress in the 19th Century is on exhibit at the Bata Shoe Museum until 30 June 2016.

Jaipreet Virdi-Dhesi

Ryerson University, Ontario, Canada

doi:10.1017/mdh.2015.50

\title{
In the Shadow of Ebola (documentary film, 27 minutes)
}

In his new film In the Shadow of Ebola, Gregg Mitman captures every family's nightmare, the choice of who to save and who to let go. Here, it is not the choice of who to pull off the tracks in the approach of a speeding train, but who to put on a flight out of Monrovia when Ebola came to call last year. Mitman's film is important and documents heroic efforts to persevere in the face of a massive calamity in a small country already traumatised by a protracted civil war (1989-2003). It is unvarnished and will upset most, but how can you sugar-coat a disease which killed more than 14000 people in one season (March 2014-2015)?

Mitman, a professor of the history of science, medicine and the environment at the University of Wisconsin, had travelled to Liberia with Emmanuel Urey, a PhD student at the University of Wisconsin, in June 2015, when it quickly became clear they would need to abandon plans for their original research project. Instead, Mitman and his collaborators, including British filmmaker Sarita Siegel and Liberian self-taught videographer Alex Wiaplah, focused their lens on Urey. Urey's two children were staying with his mother-inlaw in a small home behind the John F. Kennedy Hospital. They were thrilled to have a visit from their father, and we see happy scenes of a family reunited at the beach. Urey, who already holds a masters degree in public health, had been filled with hope, studying abroad to further his passion for improving access to medical care. Himself a former refugee of 
Liberia's civil war, he hoped to return to help build a new Liberia which appeared to be thriving under the leadership of Africa's first female president, Ellen Johnson Sirleaf.

Urey knew there was Ebola in the north of the country, but by his visit in June it was creeping silently into the capital city. With his family close to the hospital, Urey witnessed utterly heartbreaking scenes of people going there to die. He faced the difficult choice of who in his family to bring with him back to Wisconsin, where his wife Vivian and young child Emmanuel were waiting.

The story is simply and beautifully told from the perspective of a heartbroken father, with video from daily life in Wisconsin - Vivian styling her hair, a phone call to Liberia after church, a ride on an early morning bus to school, juxtaposed with equally mundane scenes of his other sons Bobby and Nelly, left in Monrovia with grandma - a call to Wisconsin, trying not to shake anyone's hand at church, looking out of the window wondering when school will reopen. Together, these scenes create a chilling cascade of vignettes until Ebola permeates every aspect of their lives and the viewer can scarcely breathe along with them.

But Mitman's documentary goes beyond the intimacy of Urey and Vivian's riveting dilemma to capture scenes from the front lines of Liberia's experience with the disease. It is hard to decide which is more upsetting: a scene of a pregnant woman dying of Ebola on a crowded city street, followed several hours later by the writhing unborn baby inside her, or the moment the government's own soldiers, desperate to maintain a quarantine in the main slum, West Point, open fire and kill a young teenage boy, not much older than Urey's son Bobby, with Mitman's film crew somehow there at just the right second to capture the shots and the young man's shouts of protest as he collapsed into the arms of a friend. Given that pregnant women had a significantly higher chance of dying once infected with Ebola, their unborn children more likely to come early and to die within several hours, and the amniotic and other fluids surrounding the birth especially likely to spread Ebola, it is almost understandable how health workers were unwilling and unable to care for a pregnant woman in those cruel circumstances. But killing citizens when death was already so unnecessary and so present? Was that all an African state in crisis had to offer?

I watched this film slowly, pausing it to cry and to mourn, unsure of whether or not to show it to college students in a history of medicine in Africa course as the crisis unfolded. It was the season of black men and women being killed on video in the streets of America, how would they handle similar, yet different, scenes from Africa? I warned them, gave them options, paused it, but they are the YouTube generation and they loved the realness of the film, its cross between viral video and reality TV. 'I love things that show you what is happening on the ground', one gushed.

And indeed, this film humanises and makes legible what has been an unfathomable and highly confusing tragedy. While the film does not explicitly mention the case of Liberian citizen Thomas Eric Duncan, whose death from Ebola in Dallas after caring for a pregnant, infected neighbour in Monrovia shortly before catching his flight to the US in October 2014 sharpened debates on immigration and international screening, Urey and Vivian closely followed other events. They waited in knots as their son Nelly sought a visa and tried to buy a plane ticket, wondering if the latest episodes might lead the US to stop all flights from Liberia and dash their chances of getting at least one family member out of Ebola's path.

For Urey's family and others in Liberia, Ebola was a completely new and novel disease. When it first came to Monrovia, people were just as confused and unlikely to suspect it as the nurse who triaged Duncan in Dallas. While there had been much smaller outbreaks since Ebola was first identified in 1976, these had all occurred thousands of miles away, 
primarily in the Democratic Republic of Congo (DRC). The largest outbreaks in the past killed no more than around 400 people, and they were rare. After a few flare-ups of the disease in the 1970s, which were spread in small towns through poor hygiene at hospitals in what was then Zaire and Sudan (now South Sudan), it did not recur until the mid-1990s. At present, no one knows precisely how Ebola entered the West Africa sub-region, heavily impacting Liberia, Sierra Leone and Guinea during 2014. It is possible that patient zero was a toddler named Emile Ouamouno in rural Guinea, who played with an infected bat around November 2013 and gave it to his mother and grandmother, who then passed it to the relatives who attended their funerals. ${ }^{1}$ But whereas DRC had poor road networks separating distant towns, making containment somewhat more straightforward in the past, Liberia, Sierra Leone and Guinea had very porous borders, with relatively high levels of mobility between towns and cities. Further, Guinea had an autocratic government with soaring levels of public distrust and both Sierra Leone and Liberia were emerging from traumatic civil wars. Schools, hospitals and clinics were all decimated, and many people had grown up in cross-border refugee camps, served as child soldiers, and generally had their doubts about those in power.

Further, Ebola in Liberia was different from Ebola in 1970s Zaire. The disease itself was less malignant, killing about $60-70 \%$ of those infected over a longer period of time. While still a strain of Ebola zaire, bleeding episodes seemed to be attenuated, leading epidemiologists to rebrand this outbreak as Ebola virus disease (EVD) rather than the Ebola haemorrhagic fever that had become the thing of legend. This meant that more people could spread the disease, and that there was a real, but small, chance of survival. There was also no known cure during the 2014 outbreak, making a hospital stay really a quarantine to limit the spread of the disease. All biomedicine could offer was slightly more efficient rehydration solutions and morphine to make death less brutal. At least in the early stages of the outbreak, those who stayed at home to wait out their infection increased their odds of dying only by about $3 \%$, but it was nearly impossible to contain their contagious vomit and diarrhoea and if they died they risked giving it to many more people than a hospital death. ${ }^{2}$ Friends and family rushed to aid their ailing relatives; the instinct to touch the ones you loved most being so difficult to override.

With In the Shadow of Ebola, Mitman moves from his previous work on nature films and seasonal allergies in the United States to a highly volatile and politicised new terrain. Along with his team, Mitman bravely documented one of the most significant events in the history of medicine at a time when many saw Ebola's approach and fled. The decision to include the shocking moments where people transitioned from difficult lives to such unfair deaths is a bold one that will hopefully bring a more nuanced understanding to what happened on the streets of Monrovia in 2014. The Urey family's willingness to allow the filmmakers to capture intimate segments from their own difficult journey with Ebola is a huge contribution. Together, Mitman and the Ureys have given all of us, not only scholars of public health and medicine, but also those who will watch the film online and through a projected television broadcast, a major gift.

Abena Dove Osseo-Asare University of Texas, Austin, TX, USA

\footnotetext{
${ }^{1}$ Almudena Marí Saéz et al., 'Investigating the Zoonotic Origin of the West African Ebola Epidemic', EMBO Molecular Medicine, 7, 1 (2015).

2 'Ebola Virus Disease in West Africa - the First 9 Months of the Epidemic and Forward Projections', New England Journal of Medicine, 371, 16 (2014).
} 